\title{
The Mysterious Fall of Soeharto: A Genre Analysis of Richard Mann’s Plots and Schemes that Brought Down Soeharto (PSBDS)
}

\author{
Sugeng Purwanto ${ }^{\mathrm{a}, *}$ \\ ${ }^{\mathrm{a}}$ Stikubank University of Semarang
}

\begin{abstract}
The real cause of Soeharto's fall from the Indonesian presidency remains a mystery. Richard Mann (1998) launched three significant rhetorical questions: (a) Was President Soeharto toppled by student demonstrators and people's power? (b) Was he brought down by the withdrawal of support from the United States? (c) Or, was his sudden fall brought about by all of the two plus large doses of Oriental plotting and scheming? This article attempts to analyze Richard Mann's PSBDS in terms of its macrostructure in order to find out the real cause of Soeharto's fall. The analysis is substantiated by different resources as linguistic evidences, to justify the validity of the findings. The study revealed a proposition that critical reading is the key to successful comprehension of a text which may include a crosschecking with other resources, a careful identification of the generic structure of a text, and paying attention to how an author positions his or her readers. The article concludes, that in fact, Soeharto resigned from presidency on his own wisdom in order to avoid more bloodshed in Indonesian dreamland.
\end{abstract}

\begin{abstract}
Abstrak
Penyebab yang sesungguhnya atas jatuhnya Soeharto dari kursi kepresidenan Indonesia masih merupakan misteri. Richard Mann (1998) melempar tiga perntanyaan retoris, yakni (a) Apakah jatuhnya Soeharto disebabkan oleh arus demonstran mahasiswa atau kekuatanmasa? (b) Apakah jatuhnya Soeharto akibat ditariknya dukungan politi kAmerikaSerikat? (c) Or, apakah jatuhnya yang mendadak disebabkan oleh kedua poin tersebut ditambah dengan banyaknya intrik oriental? Karena itu, makalah ini mencoba mencari tahu penyebab jatuhnya Soeharto. Analisis dalam kajian ini dikuatkan dengan buktibukti linguistis dari berbagai sumber agar hasil temuan menjadi valid. Penelitian ini melahirkan proposisi bahwa membaca kritis adalah kunci pemahaman teks, yang salah satunya melalui kaji ulang dengan sumber lain, mengidentifikasi struktur ginerik dan memahami arah pemosisian terhadap pembaca. Sesungguhnya, Presiden Soeharto mundur dari jabatannya atas dasar kebijaksanaannya untuk menghidari terjadinya petumpahan darah yang makin meluas di bumi pertiwi Indonesia.
\end{abstract}

Key Words: Rhetorical Questions, People’s Power, Oriental Plotting and Scheming, Macrostructure, Critical Reading

\section{Introduction}

The fall of Soeharto from Indonesian Presidency remains a mystery. Richard Mann, a British political scientist, economist, author and publisher, who specializes in Asian affairs, especially Indonesia (Mann 1998, 5) wrote a political textbook entitled Plots and Scheme that Brought down Soeharto (PSBDS). The book was published in the United Kingdom by Gateway Books in 1998. With respect to the significance of the textbook, as illustrated in its Preface, it is not

*Corresponding author. Address: J1. Tri Lomba Juang No. 01. Semarang, Indonesia.

Email: drpsugeng@yahoo.com. a mere academic exercise. Other parties, such as politicians, business people, even laymen may also be interested in reading this book to find out why President Soeharto, a 32-year-in-power regime, was brought down and by whom. Those who are in favour of political reforms may be surprised to find out the evolving attitudes and policies of the United States towards Soeharto and particularly the evolving policies of the Indonesian military. Another issue of interest in this textbook is that it deals with people who hold power as well as those who influence the power holders. In addition, the textbook shows details, event by event, accounts of everything that led to the fall of Soeharto; and is written in an interesting retrospect of time. Significantly, the textbook was written in Malaysia, Singapore and Indonesia, however, fortunately, the author was in Indone- 
sia during the month of May 1998 and at other critical times. The author, in the writing of the book, has drawn on 20 years of association and knowledge of Indonesia as well as over 30 earlier publications on investment, business and tourism (Mann 1998, 5).

As an English language educator, the author is interested in analyzing the macrostructure of Mann's PSBDS to find out the real cause of Soeharto's fall from Indonesian Presidency in terms of the generic structure of PSBD as a political textbook. The study, though, is supported by adequate linguistic evidences and is interpretative in nature, and thus subject to further verification and justification.

Theoretically, Frances Christie Martin and David Rose (2003) exemplified genre analysis in their Working with DiscourseMeaning Beyond the Clause. A genre, in this respect, refers to a staged and goal oriented social process. This is due to the fact that an individual socially participates in genres with other individuals in order to get things done by stages (step by step) to reach the goal (5). Therefore, a text of any form can be analyzed in terms of its generic structure in order to decide to what genre the text belongs to. With this, the overall organization of the text can be identified and used as a basic frame (macro-structurally established) by means of which further in-depth analysis of the text can be executed, such as locating hegemonic ideology. However, the process of genre analysis is not as easy as it reads. Each text is differently organized, depending on the type and goal of the text. In Martin and Rose's (2003) genre analysis, the text is cut by stages of development. The basic organization of a text is the Orientation $\wedge$ Incident $1-n, \wedge$ Interpretation, $\wedge$ Coda Pattern with each analysis of variables in each stage of development.

Furthermore, in an argumentative text, Martin and Rose (2003) demonstrated another pattern: Thesis $\wedge$ Arguments $1 \wedge$ Ground $1 \wedge$ Conclusion $1 \wedge$ Argument-n $\wedge$ Ground-n $\wedge$ Conclusion-n. This is only part of genre analysis, as Martin and Rose (2003) wrote: "In Tutu's original text, Helena's story follows the first Argument, supporting its conclusion, and the whole exposition is part of a longer debate” (11). Thus, the generic structure of a text follows a particular pattern.

Furthermore, in the analysis of macrostructure, it is important to know the text structure as outlined in Figure 1. The figure clearly indicates that the macrostructure is a grand part of a structure which also consists of superstructure and microstructure. It should be noted, however, that this article, being a part of a larger form of a dissertation, focuses only on the macrostructure of the text under study, just to respond to Mann's rhetorical questions printed on the back cover of PSBDS.

In other words, the analysis dealt with herein is the phylogenesis where power is contested and negotiated. Conveniently, as it was mentioned above, the article describes the macrostructure of Mann's (1998) PSBDS based on the superstructure, but ignoring the microstructure as being irrelevant.

\begin{tabular}{|c|}
\hline $\begin{array}{c}\text { Macrostructure } \\
\text { Global meaning of a text which can be observed through the topic or } \\
\text { theme of the text. }\end{array}$ \\
Superstructure \\
The organizational frame of a text, such as introduction, main body of \\
the text, closing remarks, and conclusion.
\end{tabular}

Figure 1. Text Structure

Source: Adapted by the author from Eriyana (2001, 227).

\section{Methods}

This study is qualitative and interpretative in nature, and it employs the genre analysis. Mann's (1998) PSBDS was analyzed in terms of the Superstructure and Macrostructure (Eriyana 2001) of its text in order to answer three research questions:

1. What is the generic structure of Mann's (1998) PSBDS?

2. What is the macrostructure of Mann's (1998) PSBDS?

3. What is the real cause of Soeharto's fall from presidency?

And how does it relate to Mann's (1998) rhetorical questions in his book?

The book (Mann's PSBDS) was physically examined with respect to the central theme in order to arrive at the macrostructure level of analysis, and so was it thoroughly read to find out how the book has been organized at superstructure level. The crises (moments of crises) were identified in order to be able to justify the real cause of Soeharto's fall from presidency in accordance with and in response to the author's rhetorical questions printed at the back cover of the book for commercial (marketing) purposes-for the purposes of attracting potential readers. The rhetorical questions also are raised as hints to the true cause of Soeharto's fall.

The findings have been all justified with linguistic evidences in support of the arguments. Meanwhile, the statement of the true cause of Soeharto's fall has been supported by other resources as a means of triangulation. Finally the author's stance represents how Mann (1998) organized his vested interests to position the readers within his ideological views. 


\section{Findings and Discussion}

Mann's (1998) PSBDS consists of 11 chapters, each has its own title. Chapter 1 is entitled "Sow What Ye Shall Reap." This is the generic orientation chapter which introduces, in general, the possible causes of the fall of Soeharto. It contains (a) a human right violation, (b) a security approach as a tool to maintain the status-quo, (c) several events of unrests, (d) an economic crisis, (e) process of transfer of power from Sukarno to Soeharto, and (f) Indonesian Armed Forces' (ABRI) resentment. Chapter 2 is entitled "In the Eye of the Currency Storms" as Mounting Incident 1, focusing on the economic crisis, such as falling exchange rate, high prices, International Monetary Fund (IMF) helps, social unrests, the ousting of Megawati, and the supports of reform.

Mounting Incident 2 is presented in Chapter 3 entitled "The Ides of March—Good Reason to be Aware,” discussing Soeharto's seventh appointment as president; talking about Habibie, the Vice President, followed by pro-democracy social unrests, ABRI's resentment, and the reformers speaking out to struggle. "Pius Blows the Whistle" is the title of Chapter 4 in which it highlights human right violations, including, kidnappings, missing people, further social unrests, calls for emergency session of MPR as referred to People's Consultative Assembly. Chapter 5 is entitled "Tragedy at Trisakti," in which it highlights more human right violations such as killings, rape, the divisions in the ABRI: Pro-Prabowo and ProWiranto (known as a doubled faced), Amien's Challenge to ABRI' choice, as Mounting Incident 4.

The climax of Soeharto's dramatic fall is presented in Chapter 6, entitled "I Quit," which demonstrates several issues with a clarity, including, AmienRais' and other reformists' struggle, Harmoko's requesting President's resignation, Soeharto's failed attempts to cling to power, and Soeharto's handing over the power to Habibie. The title of Chapter 7 is "Full Cycle." As Resolution 1, this chapter tries to compare the transfer of power from Sukarno to Soeharto and from Soeharto to Habibie, as well as, Soeharto's biggest mistakes and Soeharto's mismanagement of natural resources. Chapter 8 is entitled "The Habibie Government." As Resolution 2, this chapter expresses people's doubts over Habibie's reform programs, social unrests, the agreement to give him a chance, Habibie's strategies to convince people, the appointments of ministers, the preparation of a fair, multi-party general election, and the release of political prisoners. "One Nation United" is the title for Chapter 9, in which, as Resolution 3, Habibie launches his strategies to convince people, the discussions about possible returns of capital flight, and a fair treatment of ethnic Chinese.

Resolution 4 is presented in Chapter 10 entitled "Many Lids of Many Boxes" in which it demands for investigation of human right violations; most significantly, Prabowo's dismissal from the military. Chapter 11 is entitled "Prognosis" as the end of the political drama from Soeharto's regime to Habibie's transitional government. It describes issues, such as additional political prisoners released, Indonesia's future threats, opportunities, and suggestions for investment.

The above described generic structure indicates how Mann organized the development of the book event by event that led to the fall of Soeharto in rhetorical perspectives. The events indicate the ontogenetic development of the movement up to the fall of Soeharto. The 11 chapters are coherently tied together to make a unified whole. Within a paragraph, the sentences are cohesively tied employing well-structured cohesive devices.

\section{Macrostructure Analysis}

Based on the above generic structure of Mann's PSBDS, it is clear that Mann's PSBDS is organized in 11 chapters with 354 pages of which Chapter 6 entitled "I Quit" says Soeharto is meant to be the climax, followed by Habibie's regime. Finally the book ends with Chapter 11 entitled "Prognosis." The cover picture is President Soeharto in a black suit, a white shirt with a grey necktie. Right on his chest is written the title of the book Plots and Schemes that brought down Soeharto (PSBDS) printed in red, below of which the author's name Richard Mann is printed on a red banner. The picture was printed by permission from the Courtesy of Sekretariat Negara, Government of the Republic of Indonesia. Behind his right shoulder is a Red and White National Flag of the Republic of Indonesia.

Interestingly, on the back cover are, as I have mentioned earlier, printed Mann's rhetorical questions which challenge people to buy and read the book:

Was President Soeharto toppled by student demonstrations and people's power?

Or, was he brought down by the withdrawal of support from the United States? Had the outrageous business shenanigans of his family and the human rights record of his government become so shocking that the US government felt it could no longer back him, much less give him financial bailouts[?] Was the US angry with Soeharto over the cancellation of military purchases and training and his turn to Russia instead? Was the truth that he had been evicted from the presidency by a combination of people's power and the power of the people's champion, the United States?

Or, was Soeharto's sudden fall brought about by the above plus large doses of Oriental plotting and scheming? Had the worst economic crisis since the Great Depression of the 1930s 
coupled with bitter medicine from the IMF, pushed Soeharto into such a tight corner that he felt obliged to resort subterfuge to save Indonesia and his own position? Did the elements loyal to him deliberately provoke anarchic riots to demonstrate that IMF's policies were impossible to apply and to pave the way to a consolidation of power through a widespread political crackdown? Was his son-in-law pursuing agenda of his own? Aware that there would be no help or bailout for Indonesia under Soeharto, to save the state and the nation, did the military switch sides, backing reformists' demands that the ageing president step down? (Mann 1998)

The above rhetorical questions have really stimulated people to read the book in order to know the answers to the questions. In Fairclough's (1992) term, it is a kind of commodification of discourse. The answers to Mann's rhetorical questions are presented along with the linguistic evidence quoted from PSBDS and other resources (triangulation) as previously mentioned to justify the accuracy of the answers.

\section{The True Story of Soeharto's Fall}

Mann's rhetorical questions printed on the back cover of the book were, actually, meant for commercial purposes since potential readers would be encouraged to buy and read the book. There are three paragraphs printed on the back cover of PSBDS, and each of these starts a rhetorical question as the topic sentence. The rhetorical questions in Paragraph 2 are further elaborated by three other rhetorical questions. The rhetorical questions in Paragraph 3 are further elaborated by four other rhetorical questions.

In this study, however, only the rhetorical questions which are the topic sentences of the three paragraphs have been dealt with. The other rhetorical questions that elaborate the topic sentences are left unstudied since they are not significant and have been implicitly answered along with the analysis.

In order to facilitate the processes of the analysis, the three rhetorical questions are converted into statements of which the truth can be rejected or accepted by means of linguistic justification through a critical reading of the book. Thus, the statements which are derived from the rhetorical questions are:

1. President Soeharto was toppled by student demonstrators and people power.

2. President Soeharto was brought down by the withdrawal of support from the United States.

3. President Soeharto's sudden fall was brought about by all the above plus large doses of Oriental plotting and scheming.
Each of the statements will be approached one by one in order to arrive at one unified answer. With respect to Statement 1 , which states that President Soeharto was toppled by student demonstrations and people power, I think it is not true. A representative example of student demonstrations and people power is the case of Ferdinan Marcos who was forced out of office then flew to escape. President Soeharto constitutionally handed down "power" to the Vice President Habibie. Thus, the Statement 1 is rejected. The rejection of Statement 1 is also supported by Suryakusuma (2004). She wrote

People power has not emerged in Indonesia-it was not even really the students that brought down-romantic notion thought it may be. The withdrawal of support he [Soeharto] had formerly relied on made him realize his position was no longer tenable. It was surprising that the military did not seize the opportunity to stage a coup. (17)

Of course, it is true that student demonstrators to some extent contributed to the reflection of social unrests indicating dissatisfactions over the Government's handling of the monetary crisis and the wide-spread hegemonic practices of collusion, corruption and nepotism at all levels of governance. It was argued that

Objectivity was everywhere replaced by subjectivity, connections and favouritism. Corruption, collusion and nepotism flourished as never before, from the largest deals involving the most powerful people right down to the smallest unit of government and social responsibility in the village. (Mann 1998, 7)

Thus, it can be inferred that student demonstrators functioned as a prelude to the fall of Soeharto. Besides, student demonstrators were normally nullified by the security forces until the ultimate end of Soeharto Era where some of ABRI members took the students' (reformists') sides, letting the students occupy the Parliament Premises.

Statement 2 stating that President Soeharto was brought down by the withdrawal of support from the United States, is also rejected. The US's withdrawal of support only slowed down the process of bailing-out by IFM, which directly influenced the economic recovery. This, of course, to some extent, it contributed to the occurrence of more sporadic riots, more criticisms, but not the fall of Soeharto. At this point, the government critics, the Parliament, Wiranto's group persuaded President Soeharto to constitutionally resign. It is interesting to note that Wiranto was a kind of double-faced. On one hand, he seemed to support the reformists; one the other, he seemed to be loyal to Soeharto. He was very skillful in playing a "wait and see" political game. 
He [Wiranto] soon appeared on television screens to say that, the call for President Soeharto to resign from the House of Representatives faction leaders, had "no legal basis" because they represented only themselves and not the Parliament. He called for planned mass demonstrations [led by AmienRais] to be called off. The public was confused. Whose side was ABRI on? It looked as if Soeharto's time was up and as if ABRI supported the reformists but here was the ABRI commander apparently defending him! (Mann 1998, 241)

With respect to Wiranto's stance, a similar view was expressed by Suryakusuma (2004). She wrote that "People were stunned at Wiranto's statement [about Harmoko’s request for Soeharto's resignation] as he [Wiranto] hand been considered a populist and openly supportive of the people's demands for reforms” (13). Thus, it can be inferred that US's withdrawal of support was another prelude to the fall of Soeharto. It is also supported by Suryakusma's (2004) commenting that "However, external factors were also at play. The international market place had revenged the rupiah, plunging Indonesia into its worst economic crisis since Soeharto took charge” (4).

Statement 3, combined preludes to the fall of Soeharto plus overdoses of Oriental Plotting and Scheming is also rejected. Had the oriental plotting and scheming been successful, Brabowo and his men would have been able to take control of the country. He could have been the President until 2003 or at least the ABRI's high commander serving for President Habibie. The fact turned otherwise.

Since Saturday, overwhelming forces had been marshalled against the President. Wiranto's argument that it was impossible to go against such a weight of public opinion now carried the day. ABRI's high command made the decision to ask President Soeharto to resign. Wiranto and his men were safe. The Soeharto/Prabowo loyalists were finally finished (Mann 1998).

Furthermore, it was argued that "General Wiranto publicly declared that ABRI was united in its approval of Soeharto's resignation and of the constitutional hand over of power to Habibie. The use of the word 'united' pointed to a final defeat for Soeharto loyalists” (Mann 1998, 249).

Upon the rejection of the three statements, the remaining question is by whom Soeharto was really brought down. Prior to answering to the question, it is necessary to highlight what is meant by Oriental Plotting and Scheming. Luhulima (2001) stated that Soeharto suspected that Prabowo together with Habibie had been engineering strategies to topple him. As, it had been traditionally applicable to kings of Mataram to be brought down by an individual within the palace, Prabowo seemed to be planning strategies to topple the king. Luhulima (2001) continued to state, quoting Sumitro, that Tutut and Mamiek scolded Prabowo "Where the hell have you been, and why did you let the students occupy the MPR/DPR Building?” Prabowo angrily asked back whether he had to shoot the students dead! It was finally realized that Prabowo's Plots did not work. According to Luhulima (2001), one part of the chronological orders on Wednesday, 20 May 1998 at 21:50 was that Saadilah Mursjid entered to meet Soeharto and reported that Reform Committee had not yet been formed (228-229). Then, Saadilah submitted a letter of withdrawal statement by 14 ministers to Pak Harto. After reading it, Pak Harto directly declared "If that's the case, I quit.” At the same time, Pak Harto ordered to arrange his resignation as President in accordance with the Constitution. Soeharto's plan to resign soon became known all over.

Thus, Mann was very skillful. He launched rhetorical questions which encouraged potential readers to buy and read the book. However, when the questions were turned into statements, they are all rejected. In fact, critical reading using intertexual framing has finally revealed that Soeharto's resignation was due to the fact that nobody wanted to work with him. He failed to form the Reform Committee in addition to the withdrawal of 14 ministers under his cabinet and occupation of MPR/DPR (People's Consultative Assembly/House Members) building by group of students and prodemocracy activists. Soeharto also realized that clinging to power at the moment would only destroy the nation and the people. He resigned from his presidency on 21 May 1998, very solemnly, honorably and indeed constitutionally. Mann (1998) described the fall of Soeharto as follows:

President Soeharto agreed to go. At 9 am on Thursday, May 21, 32 years after coming to power, one of the world's longest serving leaders announced: 'I quit.' He had seen, he had taken advice, he had pondered, he tried to cling to power but, by the early hours of Thursday morning it must have been clear that his remaining could now lead only to the total destruction of his country-along the lines of the denouement of a James Bond movie. The prospect was for more riots, more destruction, more bloodshed and unspeakable suffering for jobless, penniless and hungry people. Around his birthplace villagers were dying of starvation.

In his resignation speech, referring obviously to the fact that no one would serve on the Reform Committee, to defections from the cabinet as well as the public position of ABRI and the Parliament, Soeharto said that it had become impossible for him to carry out his state duties. No one wanted to work with him. (Mann 1998, 248-249) 
It is therefore clear that Mann himself would answer "no" to all his own rhetorical questions. That is to say that all events were preludes to one climax event: "The failure to get his trusted people to work with (for) him” (Mann 1998). However, it is important to highlight what plots and schemes Soeharto had planned to cling to power.

Over 30 years of power had indicated how skillful Soeharto was to cling to power. He had successfully executed his plots and schemes against President Sukarno, and from there on, he institutionally implanted his vested ideology and interests at all levels of his Government. Only in the seventh term of his presidency had Soeharto miscalculated and therefore made a number of blunders leading to his fall from presidency. It was argued that "Soeharto's biggist mistake had been the unseating from the leadership of the Indonesian Democratic Party (PDI) of Megawati Sukarnoputri” (Mann 1998, 260). He simply miscalculated. In addition, upon Golkar's (Working Group Political Party) predictable victory in 1997, Soeharto had sought to pack its governing committee with family and cronies to ensure his re-election in March 1998. Again, he miscalculated. It was further argued (Artha 2007, 182) that the people's trust expressed by Harmoko as the Chairman of Golongan Karya (Golkar) on 19 October 1997 caused Soeharto to be reappointed the President, however, it was Harmoko as the Chairman of MPR who, upon pressure by the people, requested Soeharto to resign.

From the quotation above, it is clear how Soeharto felt betrayed by Harmoko who at first as the Chairman of Golkar supported Soeharto to accept the seventh term of presidency; but then Harmoko himself did otherwise, requesting Soeharto to resign by the pressure of the people. It was further argued (Artha 2007, 183) that Soeharto deserved to be pitied with respect to his life. First, he was no longer with his wife, Tien Soeharto. Second, the People suddenly did not trust him. Then, who lied? Was it true that the people trusted Soeharto to be the President? Or was Harmoko dishonest and manipulated the data? At that time Soeharto authorized the Chairman of Golkar to investigate whether or not the People still wanted him to be the President again. Soeharto asked whether the People's aspiration viewed by Golkar was correct. There is another evidence that Soeharto was really hurt when he had to step down from his Presidency. Therefore, he tried to hold his position to save himself, his family and his cronies from ruins. He also felt betrayed by Habibie as can be seen as "He [Soeharto] shook hands with the new president and at the moment of doing so he must also have realized that Habibie knew this was going to happen, that his staunchest and most loyal supporter, his adopted son, had . . . finally turned against him. Habibie tried to talk to Soeharto but he was never forgiven and every approach was rebuffed” (Mann 1998, 249).
In trying to cling to power, Soeharto was bidding to split and weaken the reform movement, dividing it between those who wanted immediate change and those who feared immediate change and would prefer a gradual transition (Mann 1998, 235). Again he miscalculated. In fact he made the reformers all the more determined. Another strategy which AmienRais (Leading Reformist) termed as "buying time" was meant for Soeharto to cling to power. It was noted that "AmienRais . . most fiery and persistent critic slammed the President's latest offer as another bid to buy time.” He was quoted as saying: "His statement [about 'soon' general election and Reform Committee] shows that he is not willing to step down and that he's ignoring the aspirations of his own people” (Mann 1998, 235).

It was a good thing that nobody wanted to join the Reform Committee, including Dr. Murcholis Madjid, and that 14 ministers signed a Statement of Withdrawal. Then, Soeharto, a five-star general who had been in power for over 30 years finally resigned wisely and constitutionally owing to his plots and schemes that turned otherwise against him (Purwanto 2007).

\section{Richard Mann's Stance}

Despite being non-Indonesian national, Mann is very knowledgeable about the Indonesian politics and economy as previously mentioned that he was in Indonesia during the month of May 1998 and at other critical times. He had drawn on 20 years of associations and knowledge of Indonesia as well as 30 years of earlier publications about investment, business and tourism. He is actually a British political scientist and economist, author and publisher, specializing in Asian affairs, especially Indonesia.

However, in writing his PSBDS, Mann had a vested interest and ideology influencing his rhetorical strategies. He presented a political propaganda worldwide-since the book was written in English. The book has presumably been read by interested people all over the world. He posted a special marketing website to achieve high sales of the book. The book can be purchased via online shopping. With such high-tech advertisements, it can even be inferred that Mann has performed institutional propaganda. It is argued (Jowett and O’Donnell 1986, 149) that "In our society advertising is institutional propaganda at its most obvious level. It serves as a constant reminder that we are being bombarded with messages intended to bring us to a certain point of view.”

The point is that as it is propaganda, it is then necessary to be read critically whatever information it presents. It is further argued that "and so we have to learn to cope with this enormous information overload” (Jowett and O’Donnell 1986, 149). Thus, critical reading has now become important - that is to say, sorting out necessary information and leaving out the unnecessary one. 
Despite being suspected of being a propagandist, one of his interesting rhetorical strategies is that Mann (1998) has positioned himself as an outside observer. The first person singular pronoun (I)—which would show "subjectivity"-was not used throughout the book, and neither was the first person plural (we)—which would ask the readers to get involved in the discussion, and neither was the second person singular/plural—which would assume the readers to be the one(s) involved in the events around the fall of Soeharto. He employed a birds-eye-view in describing the events by mentioning names (actors), places, dates, and other necessary data. Again it can be said that the book is meant for international readership. Mann's main vested interest and ideology can be seen from the diction he employed in describing the events. In terms of writing attitude, Soeharto's regime was negatively approached while the reformists were positively approached. Most importantly, Mann wanted to show to persuasively the world that it was high time Soeharto's regime had ended. Those-he warned-interested in investment in Indonesia needed a clear road map of the economic and political problems and of the prospects immediately ahead.

\section{Conclusion}

In this study, Mann's (1998) PSBDS has been analyzed in terms of its generic structure, the real cause of Soeharto's fall has been identified, and thus, it is not anymore a mystery. Soeharto resigned from his presidency on the basis of his own wisdom to avoid more bloodshed. Mann's (1998) stance has also been clearly described as an international propagandist. Being an outsider, he managed to present a step-by-step description of Soeharto's presidential fall. Interestingly, he warned that investments, despite with care, were still open.

Critical reading is the key to thorough comprehension of a text. Therefore it is recommended that reading be made a habit by means of which no information shall be missed. However, it is also important to note that one should not rely heavily on only one source for any reading topic. In other words, other books of a similar theme should also be read to check and recheck with respect to what is truth.

\section{References}

Eriyanto. 2001. Analisis Wacana: Pengantar Analisis Teks Media [Discourse Analysis: Introduction to Analysis of Media Texts]. Yogyakarta, Indonesia: LKiS.
Fairclough, Norman. 1992. Discourse and Social Change. Cambridge, Oxford, UK. Polity Press in Association with Blackwell Ltd.

Jowett, Garth S., and Victoria O’Donnell. 1986. Propaganda and Persuasion. NewBury Park, CA; London; New Delhi: Sage Publications.

Luhulima, James. 2001. Hari-Hari Terpanjang, Menjelang Mundurnya President Soeharto danbeberapaperistiwaterkait. [Long Critical Days Prior to the Resignation of President Soeharto and Other Related events]. Jakarta: Kompas Book Publisher.

Mann, Richard. 1998. Plots and Schemes that Brought Down Soeharto. Jakarta, Singapore: Gateway Books.

Martin, Frances Christie, and David Rose. 2003. Working with Discourse-Meaning beyond the Clause. London and New York. Continuum International Publishing Group.

Purwanto, Sugeng. 2007. A Critical Discourse Analysis of the Author's Rhetorical Strategies to Reveal the Struggle of Ideology in Richard Mann's Plots and Schemes that Brought down Soeharto. Doctoral Dissertation. Semarang: Semarang State University, Indonesia.

Suryakusuma, Julia I. 2004. Sex, Power and Nation. Jakarta: Metafor Publishing. 